\title{
ENHANCED ENZYMATIC ACTIVITY OF STREPTOMYCES GRISEOPLANUS L-ASPARGINASE VIA ITS INCORPORATION IN AN OIL-BASED NANOCARRIER
}

\author{
ABEER A. EL-HADIa, HANAN MOSTAFA AHMEDb', RANIA A. ZAKI ${ }^{b}$, AMIRA MOHAMED MOHSENc* \\ aNatural and Microbial Products Department, National Research Centre, Dokki, Cairo, Egypt, bChemistry of Natural and Microbial Products \\ Department, National Research Center, Dokki, Cairo, Egypt, cPharmaceutical Technology Department, National Research Centre, Dokki, \\ Cairo, Egypt
}

Email: am.mohsen@nrc.sci.eg

Received: 18 May 2020, Revised and Accepted: 24 Jun 2020

\begin{abstract}
Objective: L-asparaginase (L-asp) is a vital enzyme used as a therapeutic agent in combination with other drugs in the treatment of acute lymphoma, melanosarcoma and lymphocytic leukemia. Immobilization of enzymes through loading on nanoemulsion (NE) results in some advantages such as enhancing their stability and increasing their resistance to proteases. Aim of the present study is to formulate L-asp loaded nanoemulsion to enhance its efficiency and thermal stability.

Methods: Nanoemulsion loaded with L-asp crude extract (specific activity $13.23 \mathrm{U} / \mathrm{mg}$ protein) was prepared employing oleic acid as oil, tween 20/tween 80 as surfactants and propylene glycol (PG) as co-surfactant. L-asp loaded NE underwent several thermodynamic stability studies and the optimized formulae were further examined for their biochemical properties and thermal stability.

Results The developed formulations were spherical in shape and their sizes were in the nanometric dimensions with negatively charged zeta potential values. Upon comparing the enzyme activity of L-asp loaded NE employing tween 20 (F1) or tween80 (F4) at different concentrations, the results revealed that F4 NE showed higher enzymatic activity [323 U/ml] compared to F1 NE [197 U/ml] at the same concentration. The nanosized immobilized L-asp was more stable in the pH range from 8 to 8.5 as compared to free L-asp. The immobilized enzyme preserved about $59.11 \%$ of its residual activity at $50{ }^{\circ} \mathrm{C}$; while free L-asp preserved about $33.84 \%$.
\end{abstract}

Conclusion: In the view of these results, NE composed of oleic acid, tween 80 and PG represents a promising dosage form for enhancing the activity and stability of Streptomyces griseoplanus L-asp.

Keywords: L-asparaginase, Nanoemulsion, Streptomyces griseoplanus, Immobilization, Enzymatic activity

(C) 2020 The Authors. Published by Innovare Academic Sciences Pvt Ltd. This is an open access article under the CC BY license (http://creativecommons.org/licenses/by/4.0/) DOI: http://dx.doi.org/10.22159/ijap.2020v12i5.38360. Journal homepage: https://innovareacademics.in/journals/index.php/ijap

\section{INTRODUCTION}

L-asparaginase (L-asparagine aminohydrolase, EC 3.5.1.1) (L-asp) is a vital enzyme used as a therapeutic agent in the treatment of acute lymphoma in children, melanosarcoma, acute myelocytic leukemia chronic lymphocytic leukemia, lymphosarcoma, reticulosarcoma and Hodgkin disease [1, 2]. It has an antioxidant property [3]. L-asp is used in the manufacture of food. It can efficiently decrease the level of acrylamide up to $90 \%$ in the preparation of starchy fried foods without any alter in the final form of the product [4]

L-asp circulates in the blood system for a short time before it is broken down by proteases. This causes a limitation in its effectiveness. Thus, L-asp was usually chemically modified or physically embedded with biocompatible polymers in order to reduce the immunological response, prolong its action time and improve drug effects in blood. Preparation of an immobilized enzyme may result in a reduction in toxicity. Furthermore, immobilized enzyme significantly enhances the resistance to proteolysis with respect to native L-asp [5].

Recently, the world of science has been altered with the evolution of nanotechnology. Nanotechnology has helped scientists to think more accurately and to develop better treatments. Nanotechnology can be defined as the science which deals with the particles of nanoscale sizes. The use of nanotechnology has been amplified in the last couple of years [6]. Different kinds of pharmaceuticals have been technologically advanced by employing different nanoparticles such as nanoemulsions, nanosuspensions, nanovesicles $[7,8]$, nanospheres [9], lipid nanoparticles [10], nanotubes and nanoshells [11].

Nanoemulsions are water-in-oil or oil-in-water formulations prepared by blending oil, water, surfactant and cosurfactant in the right proportion by using high-stress mechanical extrusion [12] They are non-equilibrium systems with a spontaneous tendency to phase separation (substantial separation of the dispersed phase from the dispersant). Nevertheless, they may have long kinetic stability and are reasonably resistant to creaming or sedimentation as well as to flocculation [13]. This process yields uniform droplets ranging in size from $20-200 \mathrm{~nm}$ in diameter [14]. These discrete droplets owing to their size selectively fuse with bacterial cell walls by destabilizing their lipid envelope [12]. Due to this property, they are included in the Generally Regarded as Safe (GRAS) list and are approved for various human applications [15]

A nanoemulsion system is a good applicant for oral delivery of poorly water-soluble drugs due of its capability to enhance drug solubilization and thus improves its absorption in the gastrointestinal tract (GIT), because of the permeability changes induced by the surfactant. NEs are one of the promising systems that are prepared to enhance the bioavailability of poorly soluble drugs [14]. They have been utilized for delivery of hydrophilic, lipophilic and amphiphilic drugs through different routes of administration, such as oral, transdermal, ophthalmic and parenteral routes [4]. They can be formed on a large scale without performing high energy homogenization [14]. NEs are non-equilibrium systems having a tendency to phase separation. However, they have long kinetic stability and they resist sedimentation, creaming and flocculation [13].

Immobilization of enzymes through loading on nanoemulsion can result in some advantages, such as enhancing their stability and their resistance to proteases. The aim of the present work is to formulate and investigate L-asp loaded nanoemulsion aiming at enhancing its activity using non-irritant and pharmaceutically acceptable ingredients.

\section{MATERIALS AND METHODS}

Materials

Oleic acid was purchased from Alpha Chemika, India. Tween® 20 (extra-pure, 99\%) was obtained from VWR International, France. 
Tween ${ }^{\circledR} 80$ (extra-pure, 99\%) was procured from Riedel-de Haën Italy. Propylene glycol (PG) was purchased from BDH Laboratory, UK Methanol was procured from Fisher Scientific, UK. All chemicals are nonirritant and fall under generally regarded as safe (GRAS) category.

\section{Microorganism and cultivation conditions}

The actinomycetes strain Streptomyces griseoplanus strain isolated from some soil samples was used in the present study. The actinomycetes isolate (Streptomyces griseoplanus strain) was identified by16S rDNA, as described by El-Hadi et al. (2019) [16]. The organism was maintained on starch casein agar slants (contained in g/l: starch, 10; casein, 0.3; $\mathrm{KNO}_{3}$ 2; $\mathrm{NaCl}, 2 ; \mathrm{K}_{2} \mathrm{HPO}_{4}, 2 ; \mathrm{MgSO}_{4} .7 \mathrm{H}_{2} \mathrm{O}, 0.05 ; \mathrm{CaCO}_{3}, 0.02 ; \mathrm{FeSO}_{4} .7 \mathrm{H}_{2} \mathrm{O}, 0.01$ agar 25; pH 7) and incubated for $7-10 \mathrm{~d}$ at $28{ }^{\circ} \mathrm{C}$, and then maintained at $4{ }^{\circ} \mathrm{C}$ until further use. Inoculum was prepared from the 7-day-old culture of the strain. Adequate amounts of sterilized water were added to the optimum growth slants. Sterilized inoculating needle was used for gentle scratching of the cells. The tube was lightly shaken and transferred to 50 $\mathrm{ml}$ of sterilized inoculum medium. The inoculated flasks were incubated in the shaker at $28^{\circ} \mathrm{C}$ while shaking at $180 \mathrm{rpm}$ for $10 \mathrm{~d}$ [16].

\section{Crude enzyme extraction}

According to our optimized protocol for the overproduction of recombinant protein [17], the crude enzyme from the fermented substrate was extracted using $0.1 \mathrm{M}$ phosphate buffer $(\mathrm{pH} 8)$. After mixing the fermented substrate with $41 \mathrm{ml}$ of buffer, the flasks were kept on a rotary shaker at $150 \mathrm{rpm}$ for $30 \mathrm{~min}$. The slurry was centrifuged at $10,000 \mathrm{rpm}$ for about $10 \mathrm{~min}$ at $4{ }^{\circ} \mathrm{C}$ in a cooling centrifuge. Supernatant was collected and used for enzyme assay.

\section{Assay of L-asp activity}

L-asp activity was determined by Nessler's method. The cultures present in starch casein broth were centrifuged at $8000 \mathrm{rpm}$ for 30 min and the resultant supernatant, that is, the crude extract was used to determine the L-asp activity. Reaction was started by adding $0.5 \mathrm{ml}$ of crude cell-free extract into $0.5 \mathrm{ml}$ of $0.04 \mathrm{M} \mathrm{L}$-asparagine solution and $0.5 \mathrm{ml}$ of $0.05 \mathrm{M}$ Tris HCL buffer $\mathrm{pH} 8$ and incubated at $37{ }^{\circ} \mathrm{C}$ for 30 min in the water bath. The reaction was stopped by addition of $0.5 \mathrm{ml}$ of $1.5 \mathrm{M}$ trichloroacetic acid (TCA). Precipitated proteins were removed by centrifugation at $8000 \mathrm{rpm}$ for $15 \mathrm{~min}$ at $4{ }^{\circ} \mathrm{C}$, and the ammonia released was determined spectrophotometrically at $425 \mathrm{~nm}$. Tubes kept at zero-time incubation served as control. Enzyme activity was determined based on the liberation of ammonia calculated with reference to a standard curve of ammonium sulphate. In the concentration range of $0.1 \mathrm{ml}$ of supernatant was added to $3.75 \mathrm{ml}$ of distilled water, followed by the addition of $0.2 \mathrm{ml}$ of Nessler's reagent and was incubated at room temperature for $10 \mathrm{~min}$ after which the absorbance was taken at $425 \mathrm{~nm}$. One unit (U) of L-asp is defined as the amount of enzyme which catalyzed the formation of $1 \mu$ mole of ammonia from L-asparagine per minute under the standard assay conditions $[3,18]$

\section{Construction of pseudoternary phase diagrams}

Tween20 and Tween80 were selected to prepare nanoemulsion because of their high hydrophilic-lipophilic balance (HLB) value, which forms oil-in-water emulsion [19]. Non-ionic surfactants act by stabilizing emulsions by creating a steric barrier via the bulky molecular groups, which are directed to the continuous medium [20] Oleic acid was selected as oil, while propylene glycol (PG) was selected as co-surfactant. Aqueous titration method reported by [21] was employed to establish pseudoternary phase diagrams. A series of oil/ $S_{\text {mix }}$ mixtures were prepared at different combinations $(1: 9,2: 8$, $3: 7,4 ; 6,5: 5,6: 4,7: 3,8: 2$ and $9: 1$ ) and titrated with water to determine the nanoemulsion region. The total water consumed was recorded in terms of $\mathrm{w} / \mathrm{w}$. Visual observation was done after each addition of aqueous. The percentages of oil, $S_{\text {mix }}$ and water were plotted on ternary phase diagrams where one axis represents the $S_{\text {mix }}$, the second represents the aqueous phase and the third represents the oil phase. The endpoint of titration was recorded at the point at which the mixture appeared viscous, turbid or separated. The phase diagram was plotted employing ternary plot software (Sigma Plot for windows, version 11.0, Systat Software, Inc., Ca, USA).

\section{Preparation of $L$-asp loaded nanoemulsion}

A defined amount of the enzyme was mixed with the required amounts of surfactant. Oil and co-surfactant were added at a fixed ratio. Bi-distilled water was then added gradually. This was followed by vortexing, which required for dissolving the enzyme completely in nanoemulsion system till the formation of a transparent and homogenous nanoemulsion formulation. The developed nanoemulsions were stored at room temperature till further processing. A number of nanoemulsions with different compositions were selected from the pseudoternary phase diagrams and were subjected to further studies. The composition of selected formulations is given in table 1.

\section{Thermodynamic stability testing of the developed nanoemulsions}

The thermostability differentiates nano/microemulsions from emulsions, which will eventually phase separate [22]. The selected nanoemulsions were subjected to the following thermodynamic stability studies in order to find out the stable nanoemulsion and to discard the unstable one.

\section{Centrifugation studies}

Nanoemulsions were subjected to centrifugation studies for $30 \mathrm{~min}$. at 5,000 rpm. The stable formulations did not show any phase separation or turbidity.

\section{Heating cooling cycle}

Six cycles between refrigerator temperature $\left(4{ }^{\circ} \mathrm{C}\right)$ and $40{ }^{\circ} \mathrm{C}$ with storage of $48 \mathrm{~h}$ were performed. The formulations that did not show any phase separations, creaming or cracking were subjected to freeze-thaw cycle study.

\section{Freeze-thaw cycle}

Nanoemulsions were kept at- $20^{\circ} \mathrm{C}$ in a deep freezer for $24 \mathrm{~h}$. This was followed by transferring the nanoemulsions to room temperature $\left(25 \pm 2{ }^{\circ} \mathrm{C}\right)$ to be kept there for another $24 \mathrm{~h}$. This cycle was repeated three times. The formulations which were stable after finishing the three freeze-thaw cycles were subjected to dispersibility study.

Table 1: Composition, thermodynamic stability and dispersibility studies of the developed L-Asp NE formulations

\begin{tabular}{|c|c|c|c|c|c|c|c|c|c|c|}
\hline \multirow[t]{2}{*}{ Formulae } & \multirow{2}{*}{$\begin{array}{l}\text { Oil } \\
\text { (\%) }\end{array}$} & \multicolumn{2}{|c|}{ Surfactant (\%) } & \multirow{2}{*}{$\begin{array}{l}\text { Co- } \\
\text { surfactant }\end{array}$} & \multirow[t]{2}{*}{ Water (\%) } & \multirow[t]{2}{*}{ Heat/Cool } & \multirow[t]{2}{*}{ Centrifugation } & \multirow[t]{2}{*}{ Freeze } & \multicolumn{2}{|c|}{ Dispersibility } \\
\hline & & Tw20 & Tw80 & & & & & & Grade & Result \\
\hline F1 & 10 & 40 & -- & 40 & 10 & $\sqrt{ }$ & $\sqrt{ }$ & $\sqrt{ }$ & A & Passed \\
\hline F2 & 20 & 35 & -- & 35 & 10 & $\sqrt{ }$ & $\sqrt{ }$ & $\sqrt{ }$ & $\mathrm{D}$ & Failed \\
\hline F3 & 30 & 30 & -- & 30 & 10 & $\sqrt{ }$ & $\sqrt{ }$ & $\sqrt{ }$ & E & Failed \\
\hline $\mathrm{F} 4$ & 10 & -- & 40 & 40 & 10 & $\sqrt{ }$ & $\sqrt{ }$ & $\sqrt{ }$ & $\mathrm{A}$ & Passed \\
\hline F5 & 20 & -- & 35 & 35 & 10 & $\sqrt{ }$ & $\sqrt{ }$ & $\sqrt{ }$ & $\mathrm{D}$ & Failed \\
\hline F6 & 30 & -- & 30 & 30 & 10 & $\sqrt{ }$ & $\sqrt{ }$ & $\sqrt{ }$ & $\mathrm{E}$ & Failed \\
\hline
\end{tabular}

*All formulations were prepared at $\mathrm{S}_{\text {mix }}$ ratio of $1: 1$.

\section{Dispersibility study}

When a nanoemulsion formulation is diluted with GIT fluids, phase separation may occur, leading to precipitation of a poorly soluble drug. For parenteral and oral NE this dilution process will result in desorption of surfactant located at the globule interface. In the present study, the dispersion medium used was distilled water. An amount of $1 \mathrm{ml}$ of each selected NE formulation was added to $500 \mathrm{ml}$ 
of distilled water in a glass beaker with gentle agitation by placing it on a hotplate magnetic stirrer, with temperature adjusted to $37 \pm 0.5$ ${ }^{\circ} \mathrm{C}$, stirred at $50 \mathrm{rpm}$. The self-emulsification efficiency of each formulation was visually assessed using the following grading system [23]:

Grade A: Forms NE rapidly (within $1 \mathrm{~min}$ ), with a clear appearance.

Grade B: Forms NE rapidly with a less clear emulsion.

Grade C: Forms milky emulsion within 2 min.

Grade D: Forms grayish-white emulsion with some oily appearance (longer than $2 \mathrm{~min}$ )

Grade E: Poor or minimal emulsification having large oil globules on the surface.

Formulations that passed dispersibility tests in Grade A and B were chosen for further studies.

\section{Characterization of L-Asp loaded nanoemulsion}

\section{Transmission electron microscopy (TEM)}

The morphology of the developed L-asparaginase NE was investigated using TEM. A drop of the NE formulation was placed on the grid. This was followed by a drop of phosphotungstic acid (1 \%) The grid was then tapped on a filter paper and the samples were then examined by TEM (JEOL Co., JEM-2100, Tokyo, Japan) at different magnification powers.

\section{Droplet size}

The droplet size, size distribution and polydispersity index (PDI) of the developed formulations were determined by dynamic light employing scattering Zeta-Sizer (Malvern, Nano Series 2590, Malvern Instruments, Ltd., UK). $1 \mathrm{ml}$ of the formulation was taken in a volumetric flask and diluted with $50 \mathrm{ml}$ bi-distilled water. The droplet size of the resultant emulsions was then determined. All measurements were performed in triplicate. Data were represented as droplet size (mean \pm SD).

\section{Zeta potential (ZP)}

The ZP of the developed nanoemulsions was determined by laser diffraction analysis employing Zeta-Sizer (Malvern, Nano Series 2,590, Malvern Instruments, Ltd., UK). The samples were diluted at a ratio of $1: 50(\mathrm{v} / \mathrm{v})$ with bi-distilled water. All measurements were performed in triplicate. Data were represented as droplet size (mean \pm SD).

\section{Optimization of enzyme loading}

Two L-asp loaded NE formulations, namely F1 and F4 were selected for further investigations owing to their highest stability. In order to investigate the optimal enzyme activity, these NEs were loaded with four different concentrations of protein, namely; 5, 7.5, 10 and 15\% $(\mathrm{v} / \mathrm{v})$. These NEs were prepared according to the procedure previously mentioned.

Optimum pH and temperature studies

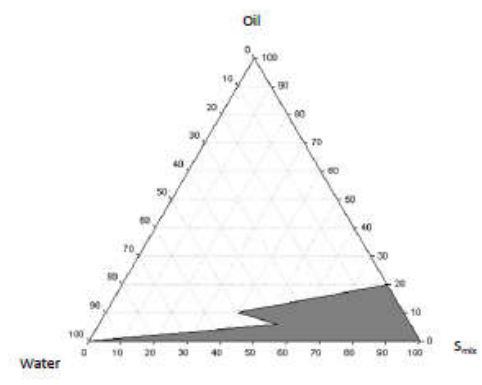

The optimum $\mathrm{pH}$ was determined by measuring enzymatic activity employing different buffers with various $\mathrm{pH}$ values as: $0.1 \mathrm{M}$ citratephosphate buffer ( $\mathrm{pH}$ 5.0-7.0) and 0.1 M Tris-HCl buffer ( $\mathrm{pH} 8-9$ ) Optimum temperature was assayed by measuring activity with varying temperatures ranging from 30 to $55{ }^{\circ} \mathrm{C}$ for $30 \mathrm{~min}$ using $2.0 \% \mathrm{~L}$-asp as a substrate at the optimum $\mathrm{pH}$ values.

\section{Determination of activation energy $\left(E_{a}\right)$}

The activation energy was determined employing the slope of a linear plot of the log of the enzyme activity (v) versus $1 / \mathrm{T}$. The enzyme activity (v) was expressed in $U$ (mg protein) $)^{-1}$, the temperature $(\mathrm{T})$ in Kelvin $(\mathrm{K})$, the gas constant $(\mathrm{R})=1.987 \mathrm{cal} \mathrm{K}^{-1} \mathrm{~mol}^{-1}$ and the activation energy ( $\mathrm{E}_{\mathrm{a}}$ ) was expressed in $\mathrm{Kcal} \mathrm{mol}^{-1}$ [24].

\section{Thermal stability of L-asp nanoemulsion}

The thermostability of the nano-immobilized enzyme was determined by incubating the biocatalyst at $30-60{ }^{\circ} \mathrm{C}$ for 15,30 , and $60 \mathrm{~min}$ in a water bath. Residual activity in samples without incubation was taken as $100 \%$. The deactivation rate constants, $\mathrm{K}$ and the half-life time, $\mathrm{t}^{1 / 2}$, were calculated using the following equation [25]:

Half-life $=0.693 /$ slope of the linear plot of log of the enzyme relative activity versus time of exposure, where deactivation rate constant $(\mathrm{K})$ $=$ slope of the straight line.

\section{Statistical analysis}

Data were expressed as mean values \pm standard deviation (SD) Statistical analysis was performed using the SPSS software (version 22.0; IBM Corporation, Armonk, NY). The significance of differences between the mean values was determined by one-way analysis of variance (ANOVA) followed by Fisher LSD's post hoc test, and a $p$ values $<0.05$ were considered statistically significant.

\section{RESULTS AND DISCUSSION}

A partially purified preparation was attained by filtration of the broth to obtain a crude extract (specific activity $13.23 \mathrm{U} / \mathrm{mg}$ protein). L-asp nanoemulsion was formulated employing oleic acid as oil Tween 20/Tween 80 as surfactants and PG as co-surfactant. The optimized formulations were characterized via several methods, including droplet size, zeta potential determination and TEM. The efficiency of the enzyme nanoemulsion was evaluated according to different parameters, including the retained enzyme activity.

\section{Construction of phase diagrams}

The phase diagrams represent a significant part in considering the phase behavior of the developed nanoemulsions. For the construction of phase diagrams, oleic acid was employed as the oil phase, Tween 20/Tween 80 as surfactants and PG as co-surfactant. Fig. 1 reveals the constructed phase diagrams. Nanoemulsion areas (grey shaded areas) represent clear isotropic systems. The results showed that using either Tween 20 or Tween 80 as surfactant and PG as cosurfactant at $S_{\text {mix }}$ ratio (1:1), a transparent isotropic nanoemulsion was formed employing not more than $20 \%$ oil.

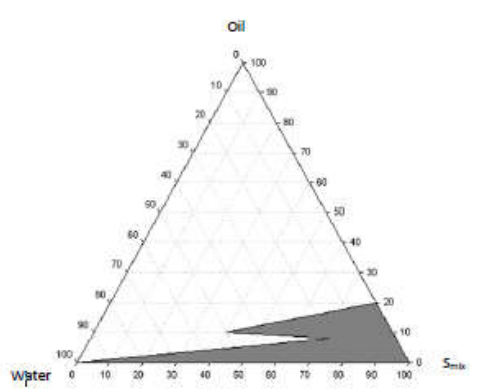

Fig. 1: Pseudoternary phase diagrams composed of oleic acid (oil), water and (a) Tween 20: PG (b) Tween 80: PG at $S_{\text {mix }}$ ratio 1:1, showing the clear $o / w$ nanoemulsion region as grey shaded regions 


\section{Thermodynamic stability testing}

To check the stability of the selected NEs, the formulations were exposed to centrifugation study, heating and cooling cycle and freeze-thawing cycle to eliminate the metastable ones [26]. Table 1 reveals that all investigated nanoemulsions passed all the thermodynamic studies performed. They were stable against centrifugation, heating cooling cycle as well as freeze-thaw cycles, without showing any phase separation, turbidity or coagulation Thus, they were further subjected to dispersibility study.

\section{Dispersibility study}

Dispersibility study results, presented in table 1 , revealed that the formulations containing $10 \%$ oil with either Tween 20 (F1) or Tween 80 (F4), succeeded to pass the dispersibility test. On the other hand, those containing $20 \%$ oil (F2 and F5) or $30 \%$ oil (F3 and F6) showed grades D or E, thus failed to pass the test and were eliminated from further studies. The results revealed that the increase in oil concentration (F2, F3, F5 and F6), needed more time for emulsification. This can be attributed to the high interfacial tension between the volume of oil and aqueous phase resulting in a net decrease in the surfactant system. This leads to longer emulsification time $[23,27]$. Those formulations that passed the dispersibility test were subjected to further characterization.

\section{Characterization of L-asp NE}

\section{Transmission electron microscopy}

The micrograph of L-asp nanoemulsion, presented in fig. 2, show that the nanoemulsion droplets exhibited spherical morphology.

\section{Droplet size and PDI}

Smaller droplet size lead to larger interfacial surface tension and may result in rapid absorption and improvement of the drug bioavailability [18]. The results of droplet size and PDI measurement are tabulated in table 2. The mean droplet size diameters were $85.45 \pm 20.54 \mathrm{~nm}$ and $70.89 \pm 15.37 \mathrm{~nm}$ for the optimized NEs; F1 and F4, respectively. These results confirmed that the developed NE formulations were in the nanometric dimensions $(<100 \mathrm{~nm})$. It could be concluded that NE developed using Tween 80 as a surfactant exhibited comparatively smaller droplets. This can be attributed to the fact that nonpolar tail in Tween 20 is saturated and linear, while that of Tween 80 is unsaturated and twisted. This emphasizes the importance of studying the molecular geometry of non-ionic surfactants on NE droplet size [19]. PDI values were less than 0.5 , indicating high uniformity of droplet size $[28,29]$.

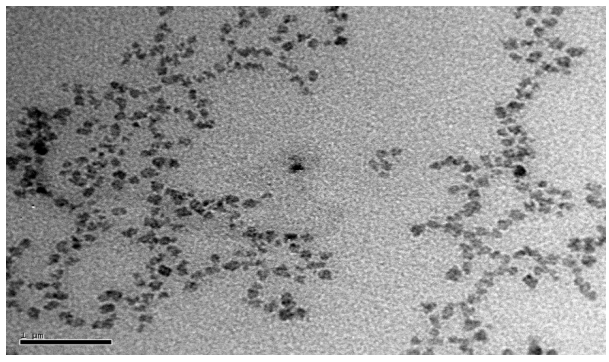

Fig. 2: TEM micrograph of selected L-asp loaded NE

Table 2: Droplet size, PDI and zeta potential of L-Asp loaded NEs

\begin{tabular}{llll}
\hline Formulation & Droplet size (nm \pm SD) & PDI & Zeta potential (mV \pm SD) \\
\hline F1 & $85.45 \pm 20.54$ & $0.241 \pm 0.13$ & $-21.3 \pm 2.63$ \\
F4 & $70.89 \pm 15.37$ & $0.279 \pm 0.08$ & $-32.5 \pm 7.76$ \\
\hline
\end{tabular}

Results are presented as mean $\pm \operatorname{SD}(n=3)$.

\section{Zeta potential}

$\mathrm{ZP}$ is considered to give an indication on the physical stability of the developed nanoemulsion. Results of ZP of optimized L-asp loaded nanoemulsions are shown in table 2 . High zeta potential values of the prepared nanoemulsion is required to generate an energy barrier that works against coalescence of the dispersed droplets [30]. ZP values of F1 and F4 nanoemulsions were-21.3 $\pm 2.63 \mathrm{mV}$ and$32.5 \pm 7.76 \mathrm{mV}$, respectively, revealing stable systems and good separation of emulsion globules [31]. It can be observed that Tween 80 nanoemulsion (F4) showed higher negatively charged ZP values when compared to Tween 20 nanoemulsion (F1), indicating higher stability of Tween $80 \mathrm{NE}$.

\section{Optimization of enzyme loading}

In order to compare the enzyme activity of L-asp loaded NE, namely F1 and F4, composed of Tween 20 and Tween 80, respectively, they were loaded with different concentrations of L-asp. The effect of different concentrations of L-asp on its activity after being incorporated in NE are shown in fig. 3. The results revealed that $\mathrm{L}$ asp nanoemulsion F4 (Tween $80 \mathrm{NE}$ ) loaded with protein $(10 \% \mathrm{v} / \mathrm{v}$ ) showed statistically higher $(p<0.05)$ enzymatic activity $[323 \mathrm{U} / \mathrm{ml}]$ when compared to the F1 (Tween $20 \mathrm{NE}$ ) loaded with the same amount of protein $[197 \mathrm{U} / \mathrm{ml}]$. Tween 80 possesses an oleate-chain with 18 carbon atoms and one unsaturated bond. It leads to a more stable $\mathrm{O} / \mathrm{W}$ interface layer and subsequently to higher emulsion stability. On the other hand, Tween 20 has saturated laurate-chains with only 12 carbon atoms. In addition, Tween 20 has a considerably higher HLB value than Tween 80; consequently, the differences in emulsion properties are easily conceivable [32]. Smaller droplet size $(70.89+15.37 \mathrm{~nm})$ of Tween80 lead to larger interfacial surface tension and may result in rapid absorption and improvement of the enzyme [33]. On the other hand, the L-asp nanoemulsion F4 loaded with $15 \%(\mathrm{v} / \mathrm{v})$ of protein showed a decrease in enzymatic activity $(164 \mathrm{U} / \mathrm{ml})$. This drop in the specific activity after nanoimmobilization could be explained by the fact that when the amount of enzyme bounded increased, too many layers of enzymes have been loaded on the nanoemulsion, and thus the surface layer prevented contact between the substrate and enzymes in lower layers.

\section{Biochemical properties of the free and the immobilized L-asp}

Two different buffers, namely $0.1 \mathrm{M}$ citrate phosphate buffer $(\mathrm{pH}$ 5-7) and 0.1 M Tris (hydroxymethyl) amino methane buffer (pH 8-9), were used to evaluate the effect of different pHs (5-9) of the reaction medium on the specific enzyme activity of L-asp nanoemulsion. The $\mathrm{pH}$ profile, shown in fig. 4 , reveals that after Lasp nano-immobilization, the optimum $\mathrm{pH}$ of the L-asp nanoemulsion exhibited an alkaline shift (pH 8-8.5). Generally, polycationic agents supports binding to enzymes, which results in shifting optimum $\mathrm{pH}$ value to alkaline ones [34]. Different variations of the free and immobilized L-asp nanoemulsion residual activity revealed that the native $\mathrm{L}$-asp preparations exhibited maximum relative activity at $\mathrm{pH}$ 8.0. These data come in accordance with El-Hadi et al. (2019) [16]. As compared with free $\mathrm{L}$-asp, the nanosized immobilized L-asp was more stable in the $\mathrm{pH}$ range from 8 to 8.5 . This indicates that the stability of L-asp is improved by immobilization in the alkaline region. These results agree with that of Dias et al. (2016), who found that L-asp from $A$. oryzae CCT 3940 exhibited optimum activity at $\mathrm{pH} 8.0$ [35]. Similar results were documented by earlier researchers working on Penicillium brevicompactum NRC 829 [36] and Streptomyces sp. [37]. Furthermore, these results agree with Meghavarnam et al. (2015) [25], who revealed that L-asp from Fusarium culmorum ASP-87 was active over a broad range of $\mathrm{pH}$, being optimum at $\mathrm{pH}$ 8.0 


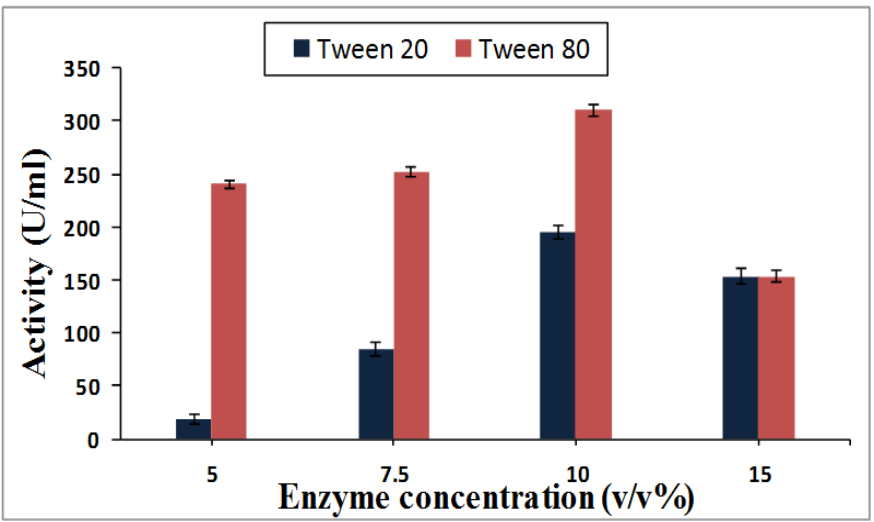

Fig. 3: Effect of different concentrations of $L$-asp on its activity after its incorporation in nanoemulsion prepared using either tween 20 or tween 80. Data are expressed as mean $\pm S D(n=3)$

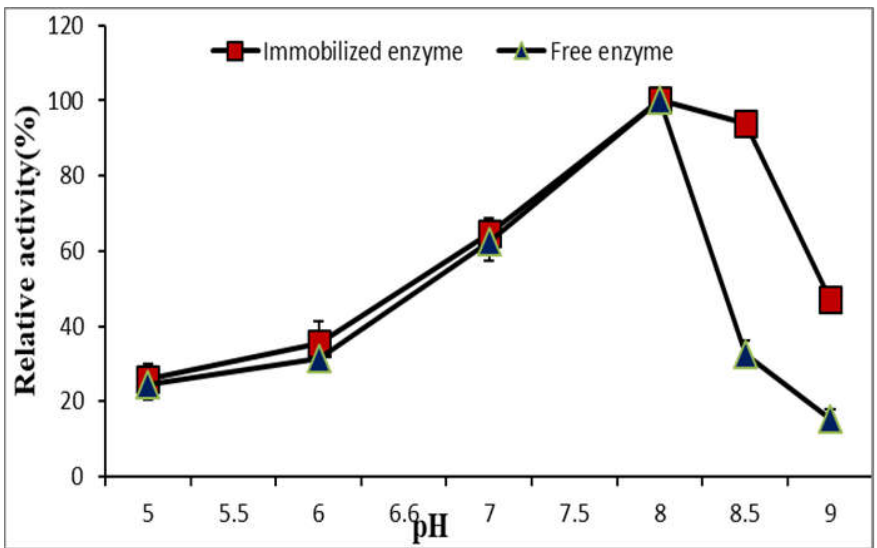

Fig. 4: Effect of assay pH on free and immobilized enzyme. Data are expressed as mean \pm SD $(n=3)$

The effect of assay temperature on the free and immobilized enzyme is demonstrated in fig. 5. The optimum reaction temperature for maximal activity was apparently shifted to $45^{\circ} \mathrm{C}$ for the free nanoemulsion enzyme. Similar results were obtained by Muharram et al. (2014) who found that the optimal temperature from a thermotolerant strain E. coli KH027 in E. coli DH5 $\alpha$ was $43{ }^{\circ} \mathrm{C}[38]$. The wild L-asp from Cladosporium $s p$. exhibited an optimum temperature and $\mathrm{pH}$ of $30{ }^{\circ} \mathrm{C}$ and 6.3 , respectively [39]. Low L-asp activity observed at higher temperatures may be attributed to partial denaturation [40]. The nano-immobilized enzyme preserved about $59.11 \pm 6.58 \%$ of its residual activity at $50{ }^{\circ} \mathrm{C}$; while, free L-asp preserved about $33.84 \pm 4.54 \%$ of its activity at the temperature of $50{ }^{\circ} \mathrm{C}$. This stabilization at high temperatures could be explained by the protection of the enzyme against the environment alterations due to its incorporation in the nanoemulsion. The activation energy of the immobilized enzyme $(1.99 \mathrm{Kcal} / \mathrm{mol})$ was lower than that of the free one $(2.93 \mathrm{Kcal} / \mathrm{mol})$.

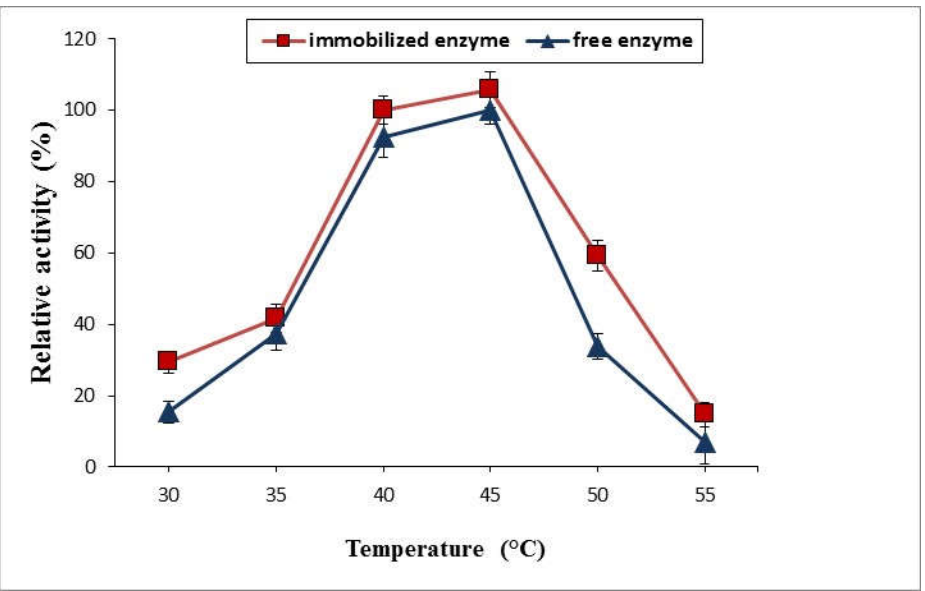

Fig. 5: Effect of assay temperature on free and immobilized enzyme. Data are expressed as mean $\pm S D(n=3)$ 


\section{Thermal stability of the nano-immobilized Streptomyces L-asp}

Thermal stability of free and immobilized L-asp residual activities is shown in fig. 6 and 7, respectively. The free enzyme exhibited a halflife of $2.88 \mathrm{~h}, 2.4 \mathrm{~h}$, and $2.16 \mathrm{~h}$ at 50,55 and $60^{\circ} \mathrm{C}$, respectively. This comes in accordance with Kumar et al. (2005) who studied the halflife of Bacillus coagulans BTS3 lipase, which was shown to be $2 \mathrm{~h}$ at $55{ }^{\circ} \mathrm{C}$ [41]. Protection of the enzymes can occur by immobilization processes. The half-life values of immobilized enzyme at 50, 55, and $60{ }^{\circ} \mathrm{C}$ were $346.5,259.87$, and $148.5 \mathrm{~min}$, respectively, which are higher than those of the free enzyme (173.25, 148.5, $129.93 \mathrm{~min})$, respectively, at the same temperatures. Full activation up to $45^{\circ} \mathrm{C}$ was achieved when L-asp was immobilized on NE. These results are similar to those obtained by Huang et al. (2014) who found that binary immobilized L-asp of Candida rugosa, at $40{ }^{\circ} \mathrm{C}$, was completely active [42]. However, inactivation of the enzyme occurred on treatment at higher temperatures. Upon exposure to 60 ${ }^{\circ} \mathrm{C}$ for $1 \mathrm{~h}$, free L-asp preserved about $60 \%$ of its residual activity, while it's immobilized one preserved about $76 \%$ of its residual activity. The thermostability of the free enzyme of Rhizopus oryzae was studied by Hiol et al. (2000) [43] who revealed inactivation at $45^{\circ} \mathrm{C}$ and complete loss of activity at $50{ }^{\circ} \mathrm{C}$ after a $40 \mathrm{~min}$ incubation. This thermal stabilization could be explained by the incorporation of L-asp in nanoemulsion, thus the enzyme was fully protected against environmental alterations. The inactivation temperature of the free and immobilized L-asp was observed to be between 50 and $60{ }^{\circ} \mathrm{C}$. Nguyen et al. reported that earlier reports on the thermostability of different L-asp preparations indicated that the native enzymes were unstable at high temperatures [44].

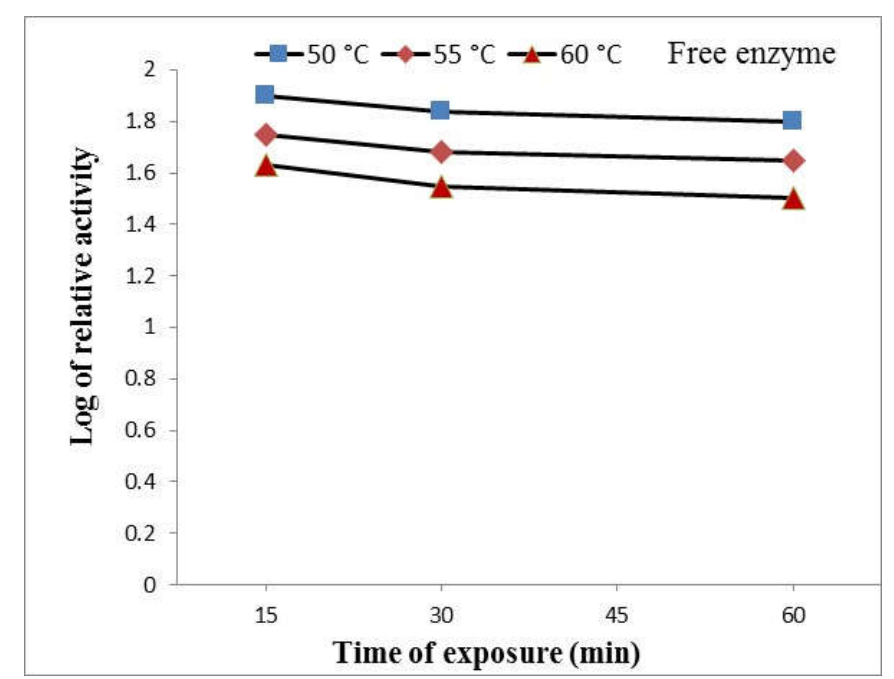

Fig. 6: Log of relative activity retained as a function of time for the free enzyme. Data are expressed as mean \pm SD $(n=3)$

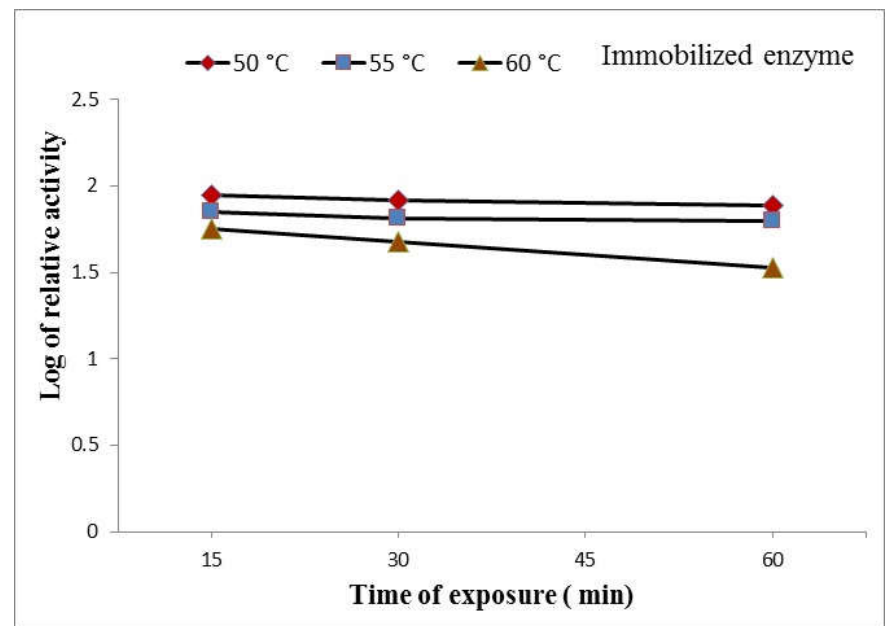

Fig. 7: Log of relative activity retained as a function of time for the immobilized L-asp enzyme. Data are expressed as mean \pm SD (n=3)

The deactivation rate constants of the immobilized L-asp for the temperatures of 50,55 and $60{ }^{\circ} \mathrm{C}$, were $2 \times 10-3,2.66 \times 10-3$, and $4.66 \times 10-3$ respectively. These constants were lower than those of the free enzyme $(4 \times 10-3,4.66 \times 10-3$ and $5.33 \times 10-3)$ at the same temperatures. Similar results were obtained by Asker et al. (2012) [45] who found that the immobilized asparaginase enzyme, obtained from Pseudomonas aeruginosa 50071, was more stable than the free enzyme where the deactivation rate constant at $50{ }^{\circ} \mathrm{C}$ for alginate immobilized L-asp was $(2.82 \times 10-2)$, which was significantly lower than that of the free asparaginase enzyme $(6.72 \times 10-2)$.

\section{CONCLUSION}

L-asp loaded NE was successfully developed and characterized. It was observed that Tween 80 NE (F4) showed significantly smaller droplet size and higher negatively charged ZP values than Tween 20 NE (F1), indicating higher stability of Tween 80 NE. The $\mathrm{pH}$ and 
thermal stability and half-life of L-asp were evaluated. The immobilized enzyme was more resistant to alkaline $\mathrm{pH}(8-8.5)$ and to high temperatures as compared to the free one. Upon comparing the thermal stability of free and immobilized L-asp residual activities at $60{ }^{\circ} \mathrm{C}$ for $1 \mathrm{~h}$, the results revealed that free L-asp preserved about $60 \%$ of its residual activity, while its immobilized one preserved about $76 \%$ of its residual activity. L-asparaginase, obtained from Streptomyces griseoplanus, was more stable when incorporated in $\mathrm{NE}$ than the free enzyme where the deactivation rate constant at $50^{\circ} \mathrm{C}$ was $2 \times 10^{-3}$ for immobilized L-asp which is lower than that of the free asparaginase enzyme $\left(4 \times 10^{-3}\right)$. These findings reveal that the incorporation of L-asp in nanoemulsion effectively enhanced the activity of L-asp. Thus, it can be concluded that nanoemulsion could be a potential drug delivery system for increasing the stability and activity of L-asparaginase.

\section{FUNDING}

Nil

\section{AUTHORS CONTRIBUTIONS}

All the authors have contributed equally.

\section{CONFLICT OF INTERESTS}

The authors report no conflict of interest.

\section{REFERENCES}

1. Verma N, Kumar K, Kaur G, Anand S. L-asparaginase: a promising chemotherapeutic agent. Crit Rev Biotechnol 2007;27:45-62.

2. Amena S, Vishalakshi N, Prabhakar M, Dayanand A, Lingappa K. Production, purification and characterization of L-asparaginase from streptomyces gulbargensis. Braz J Microbiol 2010;41:173-8.

3. Stecher A, De Deus PM, Polikarpov I, Abrahao Neto J. Stability of L-asparaginase: an enzyme used in leukemia treatment. Pharm Acta Helv 1999;74:1-9.

4. Reynolds D, Taylor J. The fungal holomorph: mitotic meiotic and pleomorphic speciation. $\mathrm{CAB}$ Int Wallingford UK 1993;4:293-301.

5. Klibanov AM. Immobilized enzymes and cells as practical catalysts. I Sci 1983;219:722-7.

6. Desai N. Challenges in the development of nanoparticle-based therapeutics. AAPS J 2012;14:282-95.

7. El-Ridy MS, Yehia SA, Mohsen AM, El-Awdan SA, Darwish AB Formulation of niosomal gel for enhanced transdermal lornoxicam delivery: in vitro and in vivo evaluation. Curr Drug Delivery 2018;15:122-33.

8. El-Ridy MS, Badawi AA, Safar MM, Mohsen AM. Niosomes as a novel pharmaceutical formulation encapsulating the hepatoprotective drug silymarin. Int J Pharm Pharm Sci 2012;4:549-59.

9. Asfour $\mathrm{MH}$, Mohsen AM. Formulation and evaluation of $\mathrm{pH}$ sensitive rutin nanospheres against colon carcinoma using HCT-116 cell line. J Adv Res 2018;9:17-26.

10. Abousamra MM, Mohsen AM. Solid lipid nanoparticles and nanostructured lipid carriers of tolnaftate: design, optimization and in vitro evaluation. Int J Pharm Pharm Sci 2015;8:380-5.

11. Shah P, Bhalodia D, Shelat P. Nanoemulsion: a pharmaceutical review. Sys Rev Pharm 2010;1:24.

12. Baker Jr JR, Wright DC, Hayes MM, Hamouda T, Brisker J. Methods of inactivating bacteria including bacterial spores. Google Patents; 2000.

13. Velikov KP, Pelan E. Colloidal delivery systems for micronutrients and nutraceuticals. Soft Matter 2008;4:1964-80.

14. Aboofazeli R. Nanometric-scaled emulsions (Nanoemulsions) Iran J Pharm Res 2010;9:325-6.

15. Bouchemal K, Briançon S, Perrier E, Fessi H. Nano-emulsion formulation using spontaneous emulsification: solvent, oil and surfactant optimization. Int J Pharm 2004;280:241-51.

16. El-Hadi AA, Ahmed HM, Hamzawy RA. Optimization of culture conditions for production of L-asparaginase by a novel isolated streptomyces strain. Egypt Pharm J 2019;18:111-22.

17. El-Refai HA, Shafei MS, Mostafa H, El-Refai A-MH, El-Beih FM, Easa SM, et al. Purification, characterization and kinetic properties of Penicillium cyclopium L-asparaginase: impact of lasparaginase on acrylamide content in potato products and its cytotoxic activity. Curr Trends Biotechnol Pharm 2015;9:132-40.

18. Khamna S, Yokota A, Lumyong S. L-asparaginase production by actinomycetes isolated from some Thai medicinal plant rhizosphere soils. Int J Integr Biol 2009;6:22-6.

19. Ghosh V, Mukherjee A, Chandrasekaran N. Eugenol-loaded antimicrobial nanoemulsion preserves fruit juice against microbial spoilage. Colloids Surf B 2014;114:392-7.

20. Grigoriev DO, Miller R. Mono-and multilayer covered drops as carriers. Curr Opin Colloid Interface Sci 2009;14:48-59.

21. Azeem A, Rizwan M, Ahmad FJ, Iqbal Z, Khar RK, Aqil M, et al. Nanoemulsion components screening and selection: a technical note. AAPS PharmSciTech 2009;10:69-76.

22. Lawrence MJ, Rees GD. Microemulsion-based media as novel drug delivery systems. Adv Drug Delivery Rev 2000;45:89-121.

23. Ahmed M, Ramadan W, Rambhu D, Shakeel F. Potential of nanoemulsions for intravenous delivery of rifampicin. Die Pharmazie 2008;63:806-11.

24. Han D, Rhee JS. Characteristics of lipase-catalyzed hydrolysis of olive oil in AOT-isooctane reversed micelles. Biotechnol Bioeng 1986;28:1250-5.

25. Meghavarnam A, Janakiraman S. Purification and characterization of therapeutic enzyme L-asparaginase from a tropical soil fungal isolate Fusarium culmorum ASP-87. J Anesth Crit Care Open Access 2015;2:00064.

26. Kassem AA, Mohsen AM, Ahmed RS, Essam TM. Selfnanoemulsifying drug delivery system (SNEDDS) with enhanced solubilization of nystatin for treatment of oral candidiasis: design, optimization, in vitro and in vivo evaluation. J Mol Liq 2016;218:219-32.

27. Kanuganti S, Jukanti R, Veerareddy PR, Bandari S. Paliperidoneloaded self-emulsifying drug delivery systems (SEDDS) for improved oral delivery. J Disper Sci Technol 2012;33:506-15.

28. Parveen R, Baboota S, Ali J, Ahuja A, Vasudev SS, Ahmad SJIjop. Oil based nanocarrier for improved oral delivery of silymarin: in vitro and in vivo studies. Int J Pharm 2011;413:245-53.

29. Shakeel F, Haq N, Alanazi FK, Alsarra IA. Polymeric solid selfnanoemulsifying drug delivery system of glibenclamide using coffee husk as a low-cost biosorbent. Powder Technol 2014;256:352-60.

30. Zhao Y, Wang C, Chow AH, Ren K, Gong T, Zhang Z, et al. Selfnanoemulsifying drug delivery system (SNEDDS) for oral delivery of zedoary essential oil: formulation and bioavailability studies. Int J Pharm 2010;383:170-7.

31. Agrawal AG, Kumar A, Gide PS. Formulation of solid selfnanoemulsifying drug delivery systems using N-methyl pyrrolidone as cosolvent. J Drug Dev Ind Pharm 2015;41:594604.

32. Schmidts T, Dobler D, Nissing C, Runkel F. Influence of hydrophilic surfactants on the properties of multiple W/O/W emulsions. J Colloid Interface Sci 2009;338:184-92.

33. Balakumar K, Raghavan CV, Abdu S. Self nanoemulsifying drug delivery system (SNEDDS) of rosuvastatin calcium: design, formulation, bioavailability and pharmacokinetic evaluation. Colloids Surf B 2013;112:337-43.

34. Tabandeh MR, Aminlari M. Synthesis, physicochemical and immunological properties of oxidized inulin-l-asparaginase bioconjugate. J Biotechnol 2009;141:189-95.

35. Dias FFG, Ruiz ALTG, Della Torre A, Sato HH. Purification, characterization and antiproliferative activity of Lasparaginase from aspergillus oryzae CCT 3940 with no glutaminase activity. Asian Pac J Trop Biomed 2016;6:785-94.

36. Elshafei AM, Hassan MM, Abd M, Abouzeid E, Mahmoud DA, Elghonemy DH. Purification, characterization and antitumor activity of L-asparaginase from penicillium brevicompactum 2 NRC 829. Br Microbiol Res 2011;2:158-74.

37. El-Sabbagh SM, El-Batanony NH, Salem TA. L-Asparaginase produced by streptomyces strain isolated from Egyptian soil: purification, characterization and evaluation of its anti-tumor. Afr J Microbiol Res 2013;7:5677-86.

38. Muharram M, Abulhamd A, Salem-Bekhet MMJAjomr. Recombinant expression, purification of L-asparaginase-II from thermotolerant E. Coli strain and evaluation of its antiproliferative activity. Afr J Microbiol Res 2014;8:1610-9. 
39. Kumar NM, Manonmani H. Purification, characterization and kinetic properties of extracellular l-asparaginase produced by cladosporium sp. World J Microbiol Biotechnol 2013;29:577-87.

40. Dange V, Peshwe S. Production, purification and characterization of fungal L-asparaginase. Bionano Frontier 2011;4:162-7.

41. Kumar S, Kikon K, Upadhyay A, Kanwar SS, Gupta R Production, purification, and characterization of lipase from thermophilic and alkaliphilic Bacillus coagulans BTS-3. Protein Expr Purif 2005; 41:38-44.

42. Huang L, Liu Y, Sun Y, Yan Q, Jiang Z. Biochemical characterization of a novel L-Asparaginase with low glutaminase activity from Rhizomucor miehei and its application in food safety and leukemia treatment. Appl Environ Microbiol 2014;80:1561-9.

43. Hiol A, Jonzo MD, Rugani N, Druet D, Sarda L, Comeau LC Purification and characterization of an extracellular lipase from a thermophilic Rhizopus oryzae strain isolated from palm fruit Enzyme Microb Technol 2000;26:421-30.

44. Nguyen TTH, Nguyen CT, Le Nguyen TS, Do TT. Optimization, purification and characterization of recombinant L-asparaginase II in Escherichia coli. Afr J Biotechnol 2016;15:1681-91.

45. Asker MM, Mohamed SF, El-sayed OH. Characterization of Immobilized L-asparaginase produced from pseudomonas aeruginosa 50071 by solid-state fermentation. Biosci Biotech Res Asia 2012;9:569-76. 